\title{
ANALISIS BIAYA DIFERENSIAL DALAM PENGAMBILAN KEPUTUSAN MENERIMA ATAU MENOLAK PESANAN KHUSUS PADA USAHA KERAJINAN YANDE BATOK KELAPA DI KABUPATEN KLUNGKUNG
}

\author{
Ni Wayan Septian Korinawati ${ }^{1}$, I Wayan Suwendra ${ }^{1}$, Anjuman Zukhri ${ }^{2}$ \\ Jurusan Pendidikan Ekonomi \\ Universitas Pendidikan Ganesha \\ Singaraja, Indonesia \\ e-mail: \{septian.korinawati@yahoo.co.id ${ }^{1}$, Yc9eda@yahoo.co.id ${ }^{1}$, \\ anjuman.zukhri@yahoo.co.id $\left.{ }^{2}\right\}$
}

\begin{abstract}
Abstrak
Penelitian ini bertujuan mengetahui penerapan perhitungan biaya diferensial sebagai dasar pengambilan keputusan menerima atau menolak pesanan khusus, perbedaan hasil perhitungan dimasukkannya biaya diferensial sebagai dasar pengambilan keputusan menerima atau menolak pesanan khusus, dan alternatif yang digunakan perusahaan dalam mengambil keputusan apakah menerima pesanan khusus atau menolak pesanan khusus pada Usaha Kerajinan Yande Batok Kelapa di Kabupaten Klungkung. Jenis penelitian ini adalah deskriptif dengan pendekatan kuantitatif. Data dikumpulkan dengan metode dokumentasi dianalisis dengan analisis diferensial dengan pesanan dan tanpa pesanan khusus. Hasil penelitian menunjukkan bahwa penerapan perhitungan biaya diferensial sebagai dasar pengambilan keputusan pesanan khusus adalah dengan menjumlahkan semua biaya produksi, baik biaya variabel maupun biaya produksi tetap ditambah dengan keuntungan yang diinginkan perusahaan. Selain itu perbedaan hasil perhitungan dimasukkannya biaya diferensial sebagai dasar pengambilan keputusan menerima atau menolak pesanan khusus pada bulan Agustus 2017 diperoleh laba sebesar Rp.12.471.050,00 lebih besar dibandingkan laba yang diperoleh tanpa pesanan khusus sebesar Rp.6.163.550,00, dan alternatif terbaik yang digunakan perusahaan dalam mengambil keputusan yaitu menerima pesanan dari Armin Jerman.
\end{abstract}

Kata kunci : biaya diferensial, keputusan menerima dan menolak

\begin{abstract}
The aims of this study is to determine the application of cost differential calculation as basis of decision making for accepting or rejecting special order, the difference of calculation results entered by differential cost as the basis of decision making for accepting or rejecting and the alternative that is used by company as decision making whether accepting or rejecting special order at Usaha Kerajinan Yande Batok Kelapa in Klungkung regency. This research is descriptive analysis with quantitative approach. The data were collected by documentation method which analyzed by differential analysis with order and without special order.The results of this study shows that the application of cost differential calculation as the basis of decision making of special order which applied by company is to sum up all productions cost both variable cost as well as fixed production costs with profit that company wants, moreover, the difference of calculation results with differential cost as the basis of decision making for accepting or rejecting special order on August 2017 is obtained by Rp. 12.471.050,00 greater than profit that obtained without special order amount of Rp. 6.163.550,00, and the best alternative that is used by company in decision making is taking order from Armin Jerman.
\end{abstract}

Keywords: differential cost, accepting decision and rejecting. 


\section{PENDAHULUAN}

Perkembangan dunia usaha saat ini semakin hari semakin berkembang dan semakin maju. Perkembangan usaha yang kian berkembang dan semakin maju memicu terjadinya persaingan diantara perusahaan-perusahaan baik perusahaan berskala kecil maupun perusahaan berskala besar. Perusahaan adalah suatu organisasi yang didirikan oleh perseorangan atau kelompok yang kegiatannya melakukan usaha, baik usaha produksi maupun dalam usaha jasa.

Usaha kerajinan adalah suatu usaha yang dilakukan oleh seseorang atau sekelompok orang untuk menciptakan suatu produk atau barang yang dilakukan oleh tangan-tangan terampil manusia serta memiliki fungsi pakai atau keindahan, sehingga memiliki nilai jual yang tinggi. Produk yang dihasilkan selanjutnya akan dipasarkan sehingga perusahaan akan memperoleh laba.

Situasi ekonomi seperti sekarang ini membuat setiap perusahaan dituntut agar lebih kreatif dan efisien dalam menjalankan perusahaannya termasuk menjaga kualitas produk yang dihasilkan serta harga jual yang sesuai demikian juga juga biaya produksi yang relatif rendah untuk memperoleh keuntungan yang semaksimal mungkin.

Berhasil atau tidaknya sebuah perusahaan atau usaha bergantung pada bagaimana manajemen mengelola perusahaan tersebut. Untuk dapat mengukur berhasil atau tidaknya manajemen dalam mengelola perusahaan dapat dilihat melalui keuntungan (laba) yang diperoleh perusahaan. Dalam menjalankan tugasnya manajemen seringkali dihadapkan pada pengambilan keputusan dari berbagai macam pilihan alternatif yang disediakan. Dalam hal ini manajemen membutuhkan informasi mengenai akuntansi yang membantu manajemen dalam pengambilan suatu keputusan yang tepat untuk memenuhi suatu pesanan baik keputusan jangka panjang maupun keputusan jangka pendek.

Informasi keuangan mutlak diperlukan dalam pengambilan berbagai macam keputusan ekonomi. Sebagai suatu sistem informasi, akuntansi menghasilkan informasi keuangan melalui laporanlaporan keuangan yang didasarkan pada prinsip-prinsip dan konsep-konsep yang berlaku umum serta merupakan proses dari aktivitas sebagai berikut: pengidentifikasian (identifyng), pencatatan (recording), dan pengkomunikasian (communicating) atas peristiwa ekonomi dari suatu organisasi baik yang mencari laba maupun nirlaba kepada berbagai pihak yang berkepentingan baik interen maupun eksterern.

Menurut Jusup (2011:4) "akuntansi adalah sistem informasi yang mengukur aktivitas bisnis, mengolah data menjadi laporan, dan mengkomunikasikan hasilnya kepada pengambil keputusan". Menurut Suradi (2009:2) "akuntansi adalah suatu sistem yang mengidentifikasi, mencatat, dan mengkomunikasikan peristiwaperistiwa ekonomi dari suatu organisasi kepada para pihak yang berkepentingan".

Munurut Dunia \& Wasilah (2012) "akuntansi biaya adalah bagian dari akuntansi manajemen dimana merupakan salah satu dari bidang khusus akuntansi yang menekankan pada penentuan dan pengendalian biaya". Menurut Supriyono (2001:12) "akuntansi biaya adalah salah satu cabang akuntansi yang merupakan alat manajemen dalam memonitor dan merekam transaksi biaya secara sistematis, serta menyajikan biaya informasi biaya dalam bentuk laporan biaya".

Menurut Musmini (2013:17) "biaya adalah suatu sumberdaya yang dikorbankan (sacrified) atau dilepaskan (forgone) utuk mencapai tujuan tertentu". Menurut Lestari \& Dykha (2017) ada empat klasifikasi biaya yaitu yang pertama biaya langsung dan tidak langsung, yang kedua klasifikasi biaya menurut perilaku biaya, yang ketiga klasifikasi biaya menurut fungsi, dan yang terakhir yang keempat klasifikasi biaya menurut konsep pendekatan variabel.

Perusahaan dapat mengunakan akuntansi manajemen dalam pengambilan suatu keputusan. menurut Samryn (2013:4) "akuntansi manajemen 
merupakan bidang akuntansi yang berfokus pada penyediaan, termasuk perkembangan, dan penafsiran informasi akuntansi bagi para manajer untuk digunakan sebagai bahan perencanaan, pengendalian operasi, dan dalam pengambilan keputusan sesuai dengan fungsi tersebut, maka akuntansi manajemen dapat digunakan sebagai pendukung pelaksanaan fungsi manajemen dalam bidang riset dan pengembangan, produksi, pemasaran, distribusi dan logistik, serta pelayanan pelanggan". Menurut Musmini (2013) sistem informasi manajemen adalah sistem informasi yang menghasilkan keluaran (output) dengan menggunakan masukan (input) dan berbagai proses yang diperlukan untuk memenuhi tujuan tertentu manajemen. Informasi manajemen dapat dibagi menjadi tiga tipe yaitu: yang pertama informasi akuntansi penuh, yang kedua informasi akuntansi diferensial, dan yang terakhir yang ketiga informasi akuntansi pertanggung jawaban.

Pengambilan keputusan dalam suatu perusahaan yang dilakukan oleh manajemen dalam mengelola perusahaan sangatlah penting. Menurut Ahmad (2013) langkah-langkah dalam pengambilan keputusan meliputi: langkah pertama yaitu penentuan masalah, misalnya mengganti mesin baru dengan mesin yang lama, menutup salah satu bagian dari perusahaan dan sebagainya, langkah yang kedua mengenal dengan baik kemungkinan-kemungkinan atau alternatifalternatif yang ada, langkah yang ketiga menetapkan data dan biaya yang relevan dengan keputusan yang akan diambil dan masalahnya karena tidak semua data atau biaya relevan dengan masalah, langkah yang keempat yaitu mengevaluasi data, dengan metode yang berkaitan dengan alternatif atau evaluasi yang bagaimana seharusnya dibuat, langkah yang kelima yaitu mempertimbangkan faktor-faktor kualitatif, dan langkah yang terakhir yaitu keputusan dan alasan diambilnya.

Manajemen memerlukan informasi untuk membuat keputusan dan untuk menentukan dampak terhadap laba rugi yang akan diakibatkan oleh alternatif keputusan yang diambil. Menurut Sunarto
(2004) informasi diferensial merupakan informasi yang dihubungkan dengan pemilihan alternatif suatu tindakan tertentu dibandingkan dengan tindakan lain.

Menurut Adolph dkk (2000:236) "biaya diferensial adalah perbedaan biaya diantara sejumlah alternatif pilihan". Menurut Sunarto (2004:60) "biaya diferensial adalah biaya masa yang akan datang yang diperkirakan akan berbeda atau terpengaruh oleh suatu pengambilan keputusan pemilihan diantara berbagai macam alternatif. Biaya relevan dengan analisis yang dilakukan manajemen untuk pengambilan keputusan".

Menurut Sugiri (2005) pada umumnya manajemen menghadapi lima macam pengambilan keputusan dalam jangka pendek yaitu yang pertama menerima atau menolak pesanan khusus, yang kedua menambah atau memberhentikan departemen atau produk, yang ketiga membeli atau memproduksi sendiri, yang keempat memproses lebih lanjur setelah split-off point atau langsung menjual, dan yang terakhir yang kelima kombinasi produk. Menurut Sugiri (2005:102) menyatakan "analisis biaya diferensial adalah sebuah model pengambilan keputusan yang dapat digunakan untuk mengevaluasi perbedaan-perbedaan dalam pendapatan dan biaya yang berkaitan dengan alternatif pengambilan keputusan". Usaha Kerajinan Yande Batok Kelapa yang beralamat di Banjar Sarimertha, Desa Negari, Kecamatan Banjarangkan, Kabupaten Klungkung merupakan usaha kerajinan yang memproduksi barang kerajinan seperti mangkok, gelas, tempat permen, celengan, canting, dan boneka Batok Kelapa.

Sebelum memproduksi perusahaan mengecek kesediaan bahan baku yang akan digunakan untuk membuat kerajinan, selanjutnya bahan baku tersebut dipotong sesuai dengan pesanan, Batok Kelapa yang sudah dipotong selanjutnya akan dihaluskan menggunakan amplas pada bagian akhir adalah proses finishing dan pengemasan. Perusahaan menerima pesanan baik yang berasal dari dalam negeri maupun yang berasal dari luar negeri. 
Dalam menerima pesanan, perusahaan memproduksi berdasarkan pesanan dan massa dengan mempekerjakan karyawan semaksimal mungkin agar pesanan tersebut dapat selesai dengan tepat waktu. Pada bulan Agustus perusahaan mendapatkan pesanan khusus boneka Batok Kelapa dari Armin Jerman sebanyak 1450 unit dengan harga Rp.32.500,00 yang dimana lebih rendah dari harga normal yaitu Rp.35.000,00. Perusahaan mengalami kendala, dimana perusahaan tidak memiliki pencatatan perhitungan khusus ketika perusahaan menerima suatu pesanan di luar produk yang biasanya dibuat namun di sisi lain perusahaan mengembalikan tingkat penerimaan pesanan yang bisa melampaui biaya yang dikeluarkan.

Dalam perusahaan pengambilan suatu keputusan sangatlah penting dilakukan, jika perusahaan mengambil keputusan akan berdampak pada biaya dan pendapatan yang akan datang yang berdampak pada Laba atau Rugi perusahaan. Hal ini perlu diperhatikan perusahaan dalam pengambilan keputusan menerima atau menolak pesanan khusus, dalam menetapkan harga jual per produk kerajinan perusahaan harus memperhatikan harga jual bahan baku yang digunakan seperti buah kelapa yang didatangkan khusus dari Sulawesi Tengah mengingat persediaan kelapa di Bali minim.

Berdasarkan uraian diatas maka tujuan dari penelitian ini yaitu untuk mengetahui Penerapan perhitungan biaya diferensial sebagai dasar pengambilan keputusan menerima atau menolak pesanan khusus pada Usaha Kerajinan Yande Batok Kelapa di Kabupaten Klungkung, perbedaan hasil perhitungan dimasukkannya biaya diferensial sebagai dasar pengambilan keputusan menerima atau menolak pesanan khusus pada Usaha Kerajinan Yande Batok Kelapa di Kabupaten Klungkung, dan alternatif yang digunakan perusahaan dalam mengambil keputusan apakah menerima atau menolak pesanan khusus pada Usaha Kerajinan Yande Batok Kelapa di Kabupaten Klungkung.

\section{METODE}

Penelitian ini merupakan jenis penelitian deskriptif kuantitatif. Penelitian deskriptif kuantitatif yaitu penelitian yang menggambarkan suatu keadaan atau fenomena tertentu secara sistematis sehingga memperoleh suatu kesimpulan umum yang menggambarkan tentang apa yang diteliti serta mengolah data berupa angka-angka dan kemudian dianalisis menggunakan analisis statistik. Sugiyono (2017) variabel penelitian pada dasarnya merupakan segala sesuatu yang berbentuk apa saja yang ditetapkan oleh peneliti untuk dipelajari sehingga memperoleh informasi tentang hal tersebut kemudian ditarik kesimpulannya. Adapun variabel dalam penelitian ini adalah biaya diferensial dalam pengambilan keputusan menerima atau menolak pesanan khusus. Data yang dihasilkan berupa angka yang berasal dari laporan keuangan dan laporan produksi pesanan khusus Usaha Kerajinan Yande Batok Kelapa di Kabupaten Klungkung yang digunakan untuk pengambilan keputusan menerima atau menolak pesanan khusus, selanjutnya akan dianalisis menggunakan analisis biaya diferensial dalam pengambilan keputusan menerima atau menolak pesanan khusus serta menggunakan metode titik tertinggi dan titik terendah sebagai teknik pemisahan biaya semivariabel untuk membantu manajemen dalam mengambil keputusan yang akan diambil.

Lokasi penelitian ini dilakukan pada Usaha Kerajinan Yande Batok Kelapa yang berlokasi di Br. Sarimertha, Desa Negari, Kecamatan Banjarangkan, Kebupaten Klungkung. Subjek dalam penelitian ini adalah Usaha Kerajinan Yande Batok Kelapa di Kabupaten Klungkung. Objek penelitian ini adalah laporan keuangan Usaha Kerajinan Yande Batok Kelapa di Kabupaten Klungkung yang terdiri dari penjualan, biaya diferensial, biaya variabel, dan biaya tetap.

Penelitian ini menggunakan jenis data kuantitatif dan data kualitatif. Data kuantitatif berupa data yang berhubungan dengan biaya diferensial yang digunakan sebagai dasar pengambilan keputusan menerima atau menolak pesanan tertentu, 
sedangkan data kualitatif sejarah singkat perusahaan, struktur organisasi, dan informasi lainnya yang relevan yang dapat mendukung penelitian ini.

Sumber data yang digunakan oleh peneliti yaitu sumber data sekunder yang diperoleh peneliti dari catatan perusahaan mengenai penjualan, biaya variabel (terdiri dari biaya bahan baku, biaya overhead, biaya tenaga kerja langsung dan biaya administrasi dan penjualan), biaya tetap (yang terdiri dari biaya overhead dan administrasi dan penjualan) dan informasi lainnya yang terkait dengan penelitian ini. Metode pengumpulan data yang digunakan dalam penelitian ini adalah dokumentasi. Metode pengumpulan data dokumentasi dipergunakan untuk memperoleh data yang berkaitan dengan laporan produksi dan laporan keuangan yang timbul untuk memproduksi produk pada Usaha Kerajinan Yande Batok Kelapa di Kabupaten Klungkung dalam menerima atau menolak pesanan khusus.

Teknik analisis data yang digunakan dalam penelitian ini adalah dengan menggunakan analisis biaya diferensial dengan pesan dan tanpa pesanan khusus.

\section{HASIL DAN PEMBAHASAN Hasil}

Dalam kegiatan produksinya perusahaan seringkali dihadapkan dengan berbagai alternatif keputusan yang harus diambil oleh manajer dalam mengelola perusahaannya. Pengambilan keputusan dalam menjalankan sebuah usaha merupakan hal yang sangat penting dilakukan oleh seorang manajer dalam menjalankan usahanya dalam hal menyelesaikan permasalahan yang dihadapi oleh manajer, mengerahkan sumberdaya yang dimilikinya demi mencapai tujuan yang diinginkan oleh perusahaan. Salah satu alternatif dalam menentukan suatu keputusan yaitu menerima atau menolak pesanan khusus. Pesanan khusus adalah pesanan diluar penjualan normal, dengan pesanan khusus di luar kegiatan normal yang dilakukan oleh perusahaan, yang biasanya dengan harga yang lebih rendah dari harga jual normal. Perusahaan seringkali menerima pesanan khusus dari konsumen tanpa memikirkan laba atau rugi dengan adanya pesanan khusus tersebut. Pada bulan Agustus tahun 2017 Usaha Kerajinan Yande Batok Kelapa di Kabupaten Klungkung menerima pesanan khusus dari Armin Jerman. Pesanan khusus yang diterima oleh Usaha Kerajinan Yande Batok Kelapa di Kabupaten Klungkung yaitu boneka dari Batok Kelapa.

$\begin{array}{llr}\text { Dalam pengambilan } & \text { keputusan } \\ \text { perusahaan selama ini hanya } \\ \text { memperhitungkan keseluruhan }\end{array}$ dalam memproduksi produk dengan tambahan pendapatan yang diinginkan perusahaan dalam menjalankan usahanya. Biaya produksi adalah jumlah biaya yang dikeluarkan oleh perusahaan dalam melakukan proses produksi. Demikian halnya dengan Usaha Kerajinan Yande Batok Kelapa yang bergerak dalam bidang usaha kerajinan berbahan dasar Batok Kelapa, dalam proses produksinya Usaha Kerajinan Yande Batok Kelapa bahan baku utama yang digunakan dalam proses produksi yaitu buah kelapa. Perusahaan memperoleh suatu pesanan khusus produk boneka Batok Kelapa, pada saat perusahaan dihadapkan dengan pesanan khusus perusahaan menerima pesanan khusus tanpa memikirkan laba atau rugi yang dihadapi oleh perusahaan selain itu perusahaan tidak mempunyai pencatatan khusus saat perusahaan menerima pesanan dari pelanggan. Oleh karena itu maka diperlukan kalkulasi biaya. Untuk menganalisis apakah menerima atau menolak pesanan khusus, untuk itu diuraikan data produksi selama bulan Januari sampai dengan bulan Desember 2017 dimana peneliti berfokus pada data produksi boneka Batok Kelapa, dapat dilinat pada tabel 1. 
Tabel 1. Volume Produksi Boneka Batok Kelapa Periode Januari - Desember 2017

\begin{tabular}{llc}
\hline No & Bulan & Volume Produksi \\
\hline 1 & Januari & 500 unit \\
2 & Februari & 900 unit \\
3 & Maret & 300 unit \\
4 & April & 720 unit \\
5 & Mei & 900 unit \\
6 & Juni & 510 unit \\
7 & Juli & 300 unit \\
8 & Agustus & 1450 unit \\
9 & September & 900 unit \\
10 & Oktober & 600 unit \\
11 & November & 900 unit \\
12 & Desember & 900 unit \\
\hline & Total & 8.880 unit \\
\hline
\end{tabular}

Berdasarkan tabel 1 volume produksi pada bulan Agustus 2017 Usaha Kerajinan Yande Batok Kelapa menerima pesanan khusus diluar kapasitas normal sebanyak 1450 unit. Perusahaan menerima semua pesanan karena dengan adanya pesanan tersebut perusahaan tidak menganggur dan tetap melakukan produksinya. Adapun jumlah penjualan yang diterima selama bulan Januari-Desember 2017 nampak pada tabel

Tabel 2. Jumlah Penjualan Boneka Batok Kelapa Tahun 2017

\begin{tabular}{ccc} 
No & Bulan & Jumlah Penjualan \\
\cline { 2 - 3 } 1 & Januari & Rp. 17.500.000,00 \\
2 & Februari & Rp. 31.500.000,00 \\
3 & Maret & Rp. 10.500.000,00 \\
4 & April & Rp. 25.200.000,00 \\
5 & Mei & Rp. 31.500.000,00 \\
6 & Juni & Rp. $17.850 .000,00$ \\
7 & Juli & Rp. $10.500 .000,00$ \\
8 & Agustus & Rp. 47.125.000,00 \\
9 & September & Rp. 31.500.000,00 \\
10 & Oktober & Rp. 21.000.000,00 \\
11 & November & Rp. 31.500.000,00 \\
12 & Desember & Rp. 31.500.000,00 \\
\hline
\end{tabular}

Berdasarkan tabel 2 jumlah penjualan produksi boneka Batok Kelapa yang terjadi pada tahun 2017 sebesar Rp.307.175.000,00. Pada bulan Agustus perusahaan menerima pesanan khusus dari Armin Jerman berupa pesanan boneka Batok Kelapa sebanyak 1450 unit boneka
Rp. $307.175 .000,00$
Batok Kelapa, dari pesanan tersebut maka maka penjualan produksi boneka Batok Kelapa pada bulan Agustus sebesar Rp.47.125.000,00. Perhitungan kalkuasi biaya setelah pemisahan biaya semi variabel dapat dilihat pada tabel 3 . 
Tabel 3. Kalkulasi Biaya Produksi pada Usaha Kerajinan Yande Batok Kelapa per Pesanan Khusus Boneka Batok Kelapa pada Bulan Agustus 2017

\begin{tabular}{|c|c|}
\hline Jenis Biaya Produksi & $\begin{array}{c}\text { Jumlah Biaya } \\
\text { Produksi }\end{array}$ \\
\hline \multicolumn{2}{|l|}{$\begin{array}{l}\text { A. Biaya Variabel } \\
\text { Biaya bahan baku dan bahan penolong: }\end{array}$} \\
\hline - Buah kelapa & Rp. 17.400 .000 .00 \\
\hline - Lem super & Rp. 1.740.000,00 \\
\hline - Lem G & Rp. 2.175.000,00 \\
\hline - Lem fox & Rp. $1.740 .000,00$ \\
\hline - Semir polis & Rp. 4.350.000,00 \\
\hline - Amplas P60 & Rp. $2.900 .000,00$ \\
\hline - Amplas P120 & Rp. $2.900 .000,00$ \\
\hline - Amplas air 120 & Rp. $1.812 .500,00$ \\
\hline \multicolumn{2}{|l|}{ Biaya tenaga kerja: } \\
\hline - Tukang produksi & Rp. 2.900.000,00 \\
\hline - Tukang finishing & Rp. $2.900 .000,00$ \\
\hline Biaya listrik variabel & Rp. 243,00 \\
\hline Biaya air variabel & Rp. 52,00 \\
\hline Biaya reparasi dan pemeliharaan aktiva & Rp. 85,00 \\
\hline Biaya administrasi dan umum lainnya & Rp. 217,00 \\
\hline Total biaya variabel & Rp. $40.818 .097,00$ \\
\hline \multicolumn{2}{|l|}{ B. Biaya Tetap } \\
\hline - Gedung & Rp. 20.000.000,00 \\
\hline - Mesin & Rp. 293.333,00 \\
\hline - Biaya administrasi dan umum lainnya & Rp. 450,00 \\
\hline Total biaya tetap & Rp. 20.293.783.00 \\
\hline $\begin{array}{l}\text { Total biaya produksi per pesanan khusus } \\
\text { boneka Batok Kelapa }\end{array}$ & Rp. $61.111 .880,00$ \\
\hline
\end{tabular}

Berdasarkan perhitungan di atas maka langkah selanjutnya adalah menghitung laba rugi produksi boneka
Batok Kelapa dengan pendekatan contribution margin dapat dilihat pada tabel4.

Tabel 4.Laporan laba rugi dengan pendekatan contribution margin pada Usaha Kerajinan Yande Batok Kelapa berdasarkan pesanan khusus boneka Batok Kelapa bulan Agustus tahun 2017.

\begin{tabular}{|c|c|}
\hline $\begin{array}{l}\text { Penjualan }(900 \times \text { Rp. } 35.000,00) \ldots \ldots \ldots \ldots \ldots \ldots \ldots \ldots \ldots \ldots \ldots \ldots \ldots \ldots \ldots \ldots \ldots \ldots \ldots \ldots \ldots \ldots \ldots \ldots \ldots \ldots \ldots \ldots \\
\text { Biaya Variabel }(900 \times R p .28 .150,00)\end{array}$ & $\begin{array}{l}\text { Rp. } 31.500 .000,0 \\
\text { Rp. } 25.335 .000,0\end{array}$ \\
\hline 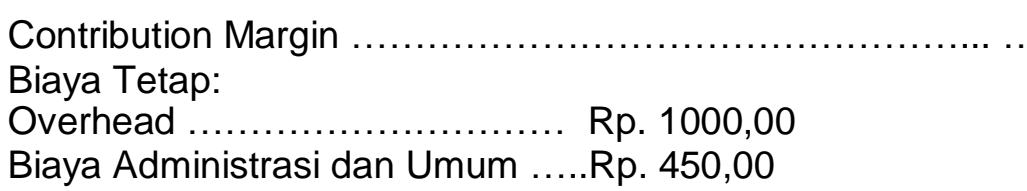 & Rp. $6.165 .000,00$ \\
\hline Jumlah Biaya Tetap ................... & (Rp. 1450,00) \\
\hline Laba Bersih & Rp. $6.163 .550,00$ \\
\hline
\end{tabular}


Berdasarkan perhitungan laba rugi dengan pendekatan contribution margin pada tabel 4 diperoleh laba bersih perusahaan pada bulan Agustus diperoleh sebanyak Rp6.163.550,00.

Dalam perusahaan keputusan menerima atau menolak pesanan khusus merupakan salah satu alternatif bagi manajemen dalam mengambil keputusan dari banyaknya alternatif keputusan yang tersedia.

Keputusan manajemen untuk menerima atau menolak pesanan khusus berpengaruh terhadap laba atau rugi perusahaan maka dari itu manajemen harus behati-hati dalam mengambil suatu keputusan jangka panjang maupun keputusan jangka pendek salah satu alternatifnya yaitu dengan perhitungan analisis biaya diferensial dengan dan tanpa pesanan khusus, untuk mengetahui perbedaan hasil perhitungan dimasukkannya biaya diferenseial sebagai dasar pengambilan keputusan menerima atau menolak pesanan khusus pada bulan Agustus dapat dilihat pada tabel 5 .

Tabel 5. Analisis diferensial dengan dan tanpa pesanan khusus bulan Agustus 2017 pada Usaha Kerajinan Yande Batok Kelapa dalam rupiah (Rp.0,00)

\begin{tabular}{cccc}
\hline Keterangan & Tanpa & Dengan & Beda \\
Pesanan & Pesanan & \\
Khusus/Tanpa & Khusus/ & \\
Biaya & Dengan Biaya & $(3)=(2)-(1)$ \\
& Diferensial & Diferensial &
\end{tabular}

(1)

(2)

\begin{tabular}{|c|c|c|c|}
\hline \multicolumn{4}{|l|}{ Penjualan: } \\
\hline $900 \times 35.000,00$ & $31.500 .000,00$ & $31.500 .000,00$ & 0 \\
\hline \multirow[t]{2}{*}{$1450 \times 32.500,0$} & - & $47.125 .000,00$ & $47.125 .000,00$ \\
\hline & $31.500 .000,00$ & $78.625 .000,00$ & $47.125 .000,00$ \\
\hline \multicolumn{4}{|l|}{ Biaya variabel: } \\
\hline $900 \times 28.150,00$ & $25.335 .000,00$ & $25.335 .000,00$ & 0 \\
\hline $1450 \times 28.150, \quad 0$ & & $40.817 .500,00$ & $40.817 .500,00$ \\
\hline Contribution mé rgin & $6.165 .000,00$ & $12.472 .500,00$ & $6.307 .500,00$ \\
\hline \multicolumn{4}{|l|}{ Biaya tetap: } \\
\hline Overhead & 1000,00 & 1000,00 & 0 \\
\hline $\begin{array}{l}\text { Admisitrasi } \\
\text { Umum }\end{array}$ & 450,00 & 450,00 & 0 \\
\hline Laba bersih & $6.163 .550,00$ & $12.471 .050,00$ & $6.307 .500,00$ \\
\hline \multicolumn{2}{|c|}{$\begin{array}{l}\text { Dada tabel } 5 \text { usaha kerajinan Yande } \\
\text { Kelapa di Kabupaten Klungkung } \\
\text { roduksi boneka Batok Kelapa rata- } \\
00 \text { unit boneka Batok Kelapa dengan } \\
\text { jual Rp. } 35.000,00 \text { maka jumlah } \\
\text { patan rata-rata boneka Batok Kelapa }\end{array}$} & $\begin{array}{l}\text { tanpa pes } \\
\text { Rp. } 31.500 .00 \\
\text { Usaha Keraj } \\
\text { menerima pes } \\
\text { unit boneka } \\
\text { jual sebesar }\end{array}$ & $\begin{array}{l}\text { han khusus sebesar } \\
\text { O. Pada bulan Agustus } \\
\text { an Yande Batok Kelapa } \\
\text { nan khusus sebanyak } 1450 \\
\text { atok Kelapa dengan harga } \\
\text { Rp.32.500,00 maka jumlah }\end{array}$ \\
\hline
\end{tabular}


pendapatan boneka Batok Kelapa dengan pesanan khusus sebanyak Rp.47.125.000,00. Perbedaan selisih laba bersih dengan dan tanpa oesanan khusus sebesar Rp.6.307.500,00, maka alternatif terbaik yang digunakan manajemen dalam mengambil keputusan apakah menerima pesanan atau menolak pesanan khusus pada Usaha Kerajinan Yande Batok Kelapa di Kabupaten Klungkung adalah menerima pesanan khusus.

\section{Pembahasan}

Berdasarkan hasil olahan data pada pembahasan di atas diperoleh perhitungan harga total biaya produksi yang dilakukan perusahaan sebesar produksi per pesanan khusus boneka Batok Kelapa Rp.35.017.500,00 : $1450=$ Rp.24.150,00. harga jual yang ditentukan perusahaan sebesar Rp. 35.000,00 dan pendapatan yang diproleh perusahaan dalam satu boneka yaitu Rp.10.850,00. Perhitungan keseluruhan kalkulasi biaya produksi pada Usaha Kerajinan Yande Batok Kelapa per pesanan khusus sebesar Rp.42.146,00 perusahaan menentukan harga jual per boneka Batok Kelapa sebesar Rp.35.000,00, kemudian dari hasil perhitungan laba rugi dengan pendekatan contribution margin diperoleh laba bersih sebesar Rp.6.163.550,00. dari hasil perhitungan harga pokok variabel diperoleh biaya variabel sebesar Rp.28.150,00.

Perbedaan hasil dimasukkannya biaya diferensial dalam mengambil keputusan menerima atau menolak pesanan khusus yang diterima oleh perusahaan berdasarkan tabel 5 Usaha Kerajinan Yande Batok Kelapa memproduksi boneka Batok Kelapa rata-rata 900 unit dengan pendapatan yang diperoleh sebesar Rp.31.500.000,00. Pada bulan Agustus perusahaan menerima pesanan khusus sebesar 1450 unit dengan harga Rp.32.500,00 maka pendapatan yang diperoleh dengan pesanan khusus sebesar Rp.47.125.000,00, selisih laba bersih dengan dan tanpa pesanan khusus setelah di masukkannya biaya diferensial sebesar Rp.6.307.500,00, sehingga keputusan alternatif yang digunakan perusahaan adalah menerima pesanan khusus.
Berdasarkan perhitungan biaya diferensial sebagai alternatif pengambilan keputusan menerima atau menolak pesanan khusus perusahaan dapat memutuskan alternatif keputusan dari adanya pesanan khusus tersebut. Hal ini sejalan dengan pendapat yang dikemukakan oleh Samryn (2015) yang menyatakan jika pendapatan tambahan lebih besar dari biaya diferensial maka pesanan khusus diterima, Jika pendapatan tambahan lebih kecil dari biaya tambahan maka pesanan khusus sebaiknya ditolak, dan Jika pendapatan tambahan sama dengan biaya tambahan maka manajemen dapat mempertimbangkan tambahan informasi dari faktor lain. Sugiri (2005) menyatakan ada lima macam keputusan yaitu menerima atau menolak pesanan khusus,menambah atau memberhentikan departemen atau produk,membeli atau memproduksi sendiri,memproses leboh lanjut setelah split-off point atau langsung menjual,dan kombinasi produk.

Pesanan khusus pada bulan Agustus menunjukkan pendapatan diferensial sebesar Rp.47.125.000,00, biaya diferensial sebesar Rp.40.817.500,00 hal ini berarti pesanan khusus pada bulan Agustus dapat diterima. Dalam hal ini berdasarkan hasil yang diperoleh sejalan dengan teori yang melandasi sama hal nya dengan penelitian terdahulu yang dikemukakan oleh Andry (2011) dan Dewi (2015) perusahaan tersebut lebih memilih menerima pesanan khusus karena berkontribusi menghasilkan laba.

\section{SIMPULAN DAN SARAN Simpulan}

Penerapan perhitungan biaya diferensial sebagai dasar pengambilan keputusan pesanan khusus yang dilakukan oleh perusahaan adalah dengan menjumlahkan semua biaya produksi baik biaya variabel maupun biaya keseluruhan yang dikeluarkan ditambah dengan keuntungan yang diinginkan perusahaan.

$$
\text { Perbedaan hasil perhitungan }
$$
dimasukkannya biaya diferensial sebagai dasar pengambilan keputusan menerima atau menolak pesanan khusus pada Usaha Kerajinan Yande Batok Kelapa di Kabupaten Klungkung, dari hasil analisis 
diferensial dalam pengambilan keputusan menerima atau menolak pesanan khusus pada bulan Agustus 2017 dapat diterima karena sesuai dengan kriteria pengambilan keputusan dalam menerima atau menolak pesanan khusus.

Alternatif terbaik yang digunakan perusahaan dalam mengambil keputusan menerima atau menolak pesanan khusus pada bulan Agustus 2017, dari hasil perhitungan laporan laba rugi dengan pendekatan contribution margin serta perhitungan analisis biaya diferensial perusahaan mengambil keputusan untuk menerima pesanan dari atas nama Armin berkebangsaan jerman Jerman pada bulan Agustus merupakan keputusan yang sangat tepat.

\section{Saran}

Berdasarkan kesimpulan diatas maka dapat dikemukakan saran sebagai berikut. Bagi Usaha Kerajinan Yande Batok Kelapa di Kabupaten Klungkung dalam memutuskan pesanan perusahaan seringkali menerima pesanan tersebut tanpa memikirkan laba rugi yang timbul dengan adanya pesanan khusus tersebut selain itu peusahaan tidak mempunyai pencatatan perhitungan khusus ketika perusahaan menerima pesanan diluar produk yang biasanya dibuat. Analisis diferensial alangkah baiknya diterapkan oleh perusahaan sehingga perusahaan dapat memutuskan unruk menerima atau menolak pesanan khusus dan dalam biaya diferensial mensyaratkan biaya variabel secara detail dalam hal ini perusahaan lebih berhati-hati dalam menerima pesanan khusus dari konsumen.

Bagi peneliti yang lain hendaknya meneliti mengenai pengambilan keputusan dengan menggunakan analisis diferensial diharapkan mampu menganalisis dengan menggunakan metode analisis yang lain yang lebih rinci sehingga perhitungan biaya yang dikeluarkan perusahaan dalam memberi keputusan dari alternatif yang ada dapat di spesifikasikan lagi. Selain itu bagi peneliti berikutnya diharapkan mampu menambahkan variabel lain serta data yang mendukung penelitian selanjutnya sehingga hasil yang diharapkan bagi peneliti selanjutnya bisa optimal.

\section{DAFTAR PUSTAKA}

Adolph, M, dkk. 2000. Akuntansi Biaya Perencanaan dan Pengendalian Jilid 2. Jakarta: Erlangga.

Ahmad, Kamaruddin. 2013. "Akuntansi Manajemen Edisi Revisi. DasarDasar Konsep Biaya dan Pengambilan Keputusan". Jakarta: PT. Raja Grafindo Persada.

Andry. 2011. "Analisis Penerapan Biaya Relevan Dalam Menerima atau Menolak Pesanan Khusus pada PT. Adinata Makasar. Skripsi Tidak Diterbitkan. Fakultas Ekonomi, Jurusan Akuntansi, Universitas Hasanuddin Makasar.

Dewi, Ni Putu Prastya. 2015. “. Analisis Pengambilan Keputusan Pesanan Khusus Dengan Menggunakan Variable Costing Pada UD Dewi Meubel". Skripsi Tidak Diterbitkan. Fakultas Ekonomi dan Bisnis, Jurusan Pendidikan Ekonomi, Universitas Pendidikan Ganesha.

Dunia, F. A \&Wasilah, A. 2012. Akuntansi Biaya Edisi 3 Jakarta: Salemba Empat

Jusup, Al Haryono. 2011. " Dasar - Dasar Akuntansi Jilid1 Edisi 7". Yogyakarta: Sekolah Tinggi Ilmu Ekonomi YKPN.

Lestari, W \& Dhyka, B, P. 2017. Akuntansi Biaya Dalam Perspektif Manajerial. Jakarta: Rajawali Pers.

Musmini, Lucy Sri. 2013. Akuntansi Manajemen. Singaraja: Undiksha Press 2013.

Samryn, L.M. 2013. Akuntansi Manajemen, Informasi Biaya untuk Mengendalikan Aktivitas Operasi \& Investasi. Jakarta: Kencana Prenada Media Group.

Sugiri,Slamet. 2005. Akuntansi Manajemen Edisi Revisi. Yogyakarta: UPP - AMP YKPN.

Sugiyono. 2017. Metode Penelitian Kuantitatif, Kualitatif, dan $R \& D$.Bandung: $\quad$ ALFABETA. 
Sunarto. 2004. Akuntansi Biaya. Edisi Revisi. Yogyakarta: Amus.

Supriyono, R,A. 2001. Akuntansi Biaya: Pengumpulan Biaya dan Penentuan Harga Pokok, Buku 1. Edisi ke dua. Yogyakarta: BPFE- Yogyakarta.

Suradi. 2009. "Pengantar Akuntansi 1". Yogyakarta: Gava Media. 